\title{
Analytical techniques for determination of mycotoxins in barley, malt and beer: A review
}

\author{
Marek Pernica ${ }^{1^{*}}$, Karim C. Piacentini ${ }^{2}$, Karolína Benešová ${ }^{1}$, Josef Čáslavský '1,3 $^{1,}$ Sylvie Běláková ${ }^{1}$ \\ Research Institute of Brewing and Malting, Mostecká 7 , \\ 61400 Brno, Czech Republic \\ 2 Biotechnology Department, University of Sao Paulo (USP), \\ Av. Professor LineuPrestes, 03178-200, Sao Paulo, Brazil \\ 3 Brno University of Technology, Faculty of Chemistry, \\ Institute of Chemistry and Technology of Environmental \\ Protection, Purkyňova 118, 61200 Brno, Czech Republic \\ * corresponding author: pernica@beerresearch.cz,
tel.: +420 545214110
}

\begin{abstract}
The increasing interest in defining the content of mycotoxins is related to the development of methods for their determination. Several methods of determination have been published. This paper describes analytical procedures such as (a) sample preparation - sampling and homogenization, (b) extraction and purification - solid phase extraction (SPE), a QuEChERS method (acronymic name from quick, easy, cheap, effective, rugged and safe), solid-liquid extraction (SLE) and immuno affinity extraction (IAE). It also provides a review of, (c) instruments, and other analytical methods such as thin layer chromatography (TLC), enzyme linked immune sorbent assay (ELISA) and liquid chromatography (LC), gas chromatography (GC) with different detectors for determination of mycotoxin in barley, malt and
\end{abstract} beer are discussed.

Keywords: mycotoxins, barley, malt, beer, chromatography, extraction

\section{Introduction}

Mycotoxins are thermostable, toxic secondary metabolites produced by several fungal species growing on many agricultural commodities and processed food, either in the field or during storage. These toxins occur naturally in plant products such as cereals, nuts, dried fruit, corn, barley and in their product such as malt and beer (Bennett \& Klich, 2003). They present a serious threat to human and animal health. The target organs for mycotoxins are the immune and haematological system, the liver, kidneys, neurological and respiratory system (Fung, \& Clark, 2004; Bolechová et al., 2014). Since the majority of secondary metabolites are synthesised in a simple biosynthetic reaction from small molecules (acetates, pyruvates, etc.), this is surprising; however, this leads to the compounds having a diverse range of toxic effects, both acute and chronic. The effects of all mycotoxins have been described in several books and reviews (Betina, 1989; Fung, \& Clark, 2004; Turner et al., 2009). In animals, aflatoxins have been demonstrated to be mutagenic, teratogenic and carcinogenic compounds, with the liver being the main target organ. OTA is a potent nephrotoxin and hepatotoxin with teratogenic, mutagenic, carcinogenic and immunosuppressive effects, even at trace levels (Zöllner \& Mayer-Helm, 2006). ZON is a non-estroidal oestrogenic toxin which has been involved in incidents of precocious pubertal changes. ZON was considered to be "not classifiable" with regard to its carcinogenicity to humans (group3). However, aflatoxins and OTA have been classified as human carcinogens (group 1), or as possible carcinogens to humans (group 2B) (International Agen- 
cy for Research on Cancer (IARC), 1993; International Agency for Research on Cancer (IARC), 2002). The European Commission has established maximum permitted levels for mycotoxins in cereals: $2 \mu \mathrm{g} \cdot \mathrm{kg}-1$ for aflatoxin B1 and $4 \mu \mathrm{g} \cdot \mathrm{kg}-1$ for the sum of aflatoxins B1, G1, B2 and G2, $5 \mu \mathrm{g} \cdot \mathrm{kg}-1$ for OTA and $100 \mu \mathrm{g} \cdot \mathrm{kg}-1$ for ZON. The limits for OTA, PAT and DON in food are $20 \mu \mathrm{g} \cdot \mathrm{kg}-1,50 \mu \mathrm{g} \cdot \mathrm{kg}-1$, $500 \mu \mathrm{g} \cdot \mathrm{kg}-1$ respectively. For baby and infant food, the limits are even stricter. These limits refer to an edible share of the raw material (without shells etc.). The limit also applies to products made from these raw materials (European Commission, 2006; Malír \& Ostrý, 2003). Most mycotoxins are chemically and structurally diverse, as shown in Table 1. Mycotoxins are produced by various fungal species belonging, essentially, to the Aspergillus, Penicillium and Fusarium genera. Nowadays, hundreds of mycotoxins have already been identified, but the most important ones regarding their occurrence and toxicity are aflatoxins (AFs), fumonisins (FMs), trichotecenes (TRC), ochratoxins (OTs), patulin and zearalenone (ZON) and their metabolites. There are many other toxicologically important mycotoxinswhich are less studied, such as ergot alkaloids, enniatins (ENs), alternaria toxins, moniliformin (MON), citrinin (CIT), beauvericin (BEA), cyclopiazonic acid, roquefortin $\mathrm{C}$, mycophenolic acid, penitrems, verruculogen, griseofulvin, citreoviridin, etc. (Pereira et al., 2014). Raw cerealslike barley, maize, rye, and malt, but also beer were often contaminated with type B-TRC particularly deoxynivalenol (DON) and nivalenol (NIV). Type A-TRC, namely T-2 and HT-2 toxins, are especially prevalent in oats (Pettersson et al., 2011). Other mycotoxins prevalent in raw cereals include AFs, FMs and ZON (Pereira et al., 2014). OTA can also be detected in beer (Běláková et al., 2015). The mycotoxinpatulin is produced by a number of fungi common to fruit- and vegetable-based products, most notably apples (Moake et al., 2005). CIT has been detected at low levels in wheat products (Zaied, Zouaoui, Bacha, \& Abid, 2012). Only a few studies were dedicated to evaluating the presence of emerging mycotoxins (FUS, BEA, ENs, MON) in raw and processed cereals. This is partly because the majority of the mycotoxins have been discovered during the last few decades, while the traditional mycotoxins are known for a much longer time. (Njumbe Ediage et al., 2011).

Barley belongs to the oldest and economically most important crops. Currently, most of barley production is
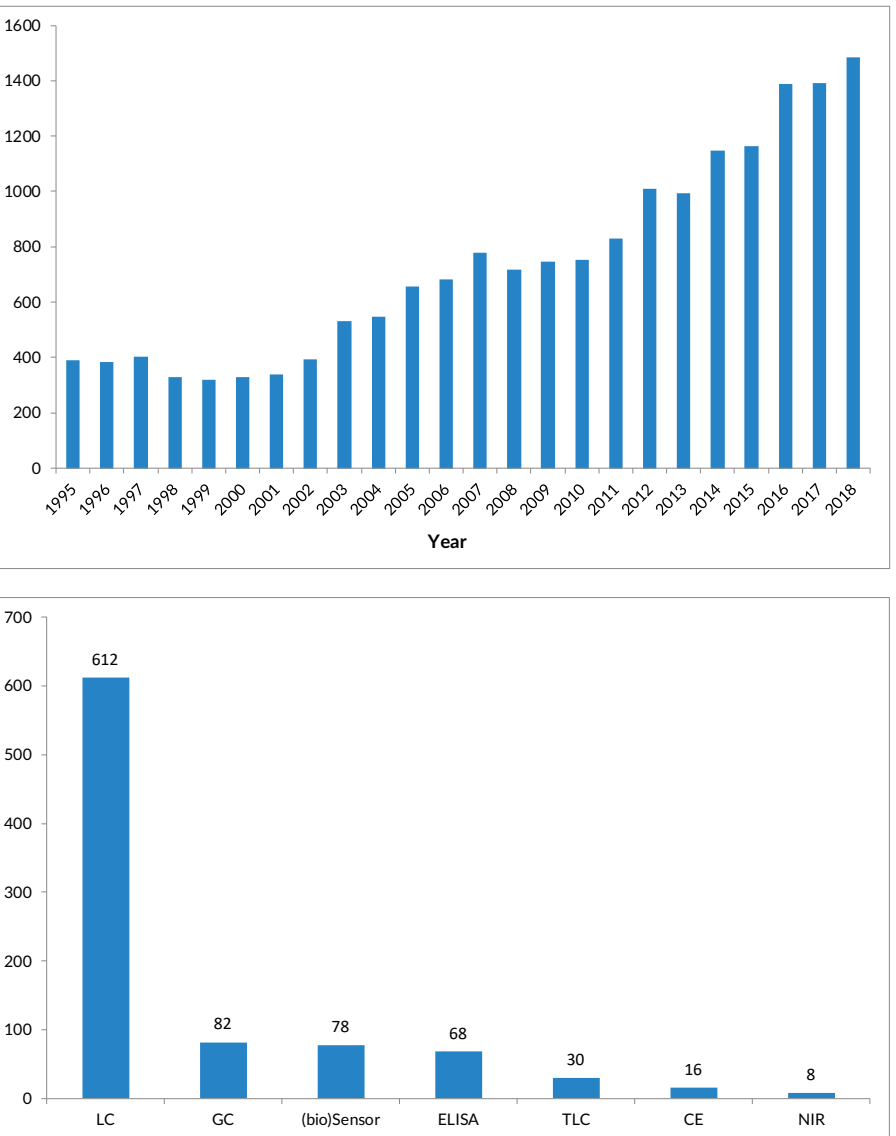

igure 1A The number of publications on "mycotoxins" in the last decades The number of publications on "mycotoxins + analytical technique from 1995-2018 (Science Direct)

used as feed; the best quality barley is used for production of malt, beer and whisky (Speijers \& Speijers, 2004). In the past, malt was prepared from a variety of cereals. Aside from water, barley (Hordeum vulgare L.) is the primary raw material used in beer production, at least in traditional brewing countries. Distinctive malt types exhibiting unique characteristics are created by adjusting the processes during malting. The biosynthesis and activity of malt enzymes are regulated over the course of these processes. Malt enzymes act on specific substances in the kernel and define the degree of degradation of the high molecular weight compounds, as well as the redox potential and acidity of malt. The degree to which the formation of color and aromatic compounds occurs can be regulated by adjusting the malt kilning process. To ensure reproducibility in beer production and the quality of the final product, it is important to use malt lots prepared from only one or at most two genetically similar barley varieties. Worldwide, pilsner malt and Munich malt are the predominant malt types used for the production of pale and dark beers, respectively. Other types of specialty malt such as wheat malt, caramel malt, coloring malt, smoked malt, melanoidin malt, diastatic malt, and proteolytic malt 
Table 1 Physico-chemical properties and structure of mycotoxins

\begin{tabular}{|c|c|c|c|c|c|}
\hline Compound & Acronym & CAS number & Molecular weight & $\log P$ & Structure \\
\hline Aflatoxin B1 & AFB1 & $1162-65-8$ & 312,27 & 1,23 & \\
\hline Aflatoxin B2 & AFB2 & 7220-81-7 & 314,29 & 1,45 & \\
\hline Aflatoxin G1 & AFG1 & $1165-39-5$ & 328,27 & 0,5 & \\
\hline Aflatoxin G2 & AFG2 & $7241-98-7$ & 330,29 & 0,71 & \\
\hline Deoxinivalenol & DON & 51481-10-8 & 296,32 & $-0,71$ & \\
\hline Zearalenon & ZON & $17924-92-4$ & 318,36 & 3,83 & \\
\hline $\mathrm{T}-2$ toxin & $\mathrm{T}-2$ & 21259-20-1 & 466,52 & 2,27 & \\
\hline HT-2 toxin & HT-2 & $26934-87-2$ & 424,49 & I & \\
\hline Ochratoxin A & OTA & $303-47-9$ & 403,81 & 4,74 & \\
\hline Patulin & PAT & $149-29-1$ & 154,12 & $-2,4$ & \\
\hline
\end{tabular}


(sour malt), are used in the production of various special beers (Basařová et al., 2017).

Beer is the oldest alcoholic beverage and the cereal-based product consumed worldwide (Rubert et al., 2013). Basic ingredients for beer production are malted barley, water, hops and yeast. Wheat may be also used (WHO, 2004). Beer is a complex matrix; in addition to ethanol and water, beer contains volatile and non-volatile compounds, monocarboxylic acids and their esters, nitrogen- and sulfur- compounds, terpenic compounds, coloring substances, tannic and polyphenolic substances and inorganic salts. The alcohol (ethanol) is a fermentation product and it can strongly influence the extraction of mycotoxins (IARC, 2010; Rubert et al., 2013). Occasionally, toxic additives and contaminants not permitted for commercial production have been identified in alcoholic beverages, but are present in alcoholic beverages due to production, processing, preparation, packing, transport or holding, or as a result of environmental contamination. Contaminants and toxic additives found in alcoholic beverages are methanol, diethyl glycol (used as sweetener), chloroacetic acid, nitrosamines, mycotoxins, pesticides and inorganic contaminants such as lead, cadmium, arsenic and organometals (Ough, 1987; IARC, 2010).

The fact that most mycotoxins are toxic in very low concentrations requires sensitive and reliable methods for their detection, generally in the $\mathrm{mg} / \mathrm{kg}, \mathrm{mg} / \mathrm{L}$ (ppm) or $\mu \mathrm{g} / \mathrm{kg}, \mu \mathrm{g} / \mathrm{L}$ (ppb) range, depending on the individual mycotoxin being analysed. Sampling of non-homogeneously distributed compounds and the analytical methods are of critical importance for the determination of mycotoxins in barley, malt and beer. In the last years, there has been a large effort to develop analytical methodologies for an effective determination of mycotoxins, particularly multi-mycotoxin methods. Due to this multitude of variables and varied structures of these compounds it is not possible to use one "gold standard" method to detect all mycotoxins and all matrices, as each will require a different method for best performance (Turner et al., 2009; Siegel \& Babuscio, 2011). Though several recently developed techniques such as QuEChERS method (acronymic name from Quick, Easy, Cheap, Effective, Rugged and Safe) or dispersive liquid-liquid microextraction (DLLME) have been used, conventional techniques like solid-phase extraction (SPE) or solid-liquid extraction (SLE) using solvent mixtures such as acetonitrile/water are still probably the attractive procedures most widely used. Antibody-based immunochemical methods such as the enzyme-linked immunosorbent assays (ELISA), immunoaffinity column assays and immunosensors are rapid, simple, specific, sensitive, and in some cases portable methods, which have been extensively used in screening analysis of mycotoxins (Pereira et al., 2014). For clean-up of mycotoxins in the different matrices can be used immunoaffinity columns (IAC) (Şenyuva \& Gilbert, 2010). Chromatographic techniques such as liquid chromatography (LC), gas chromatography (GC), liquid chromatography/ mass spectrometry (LC/MS), gas chromatography/mass spectrometry (GC/MS), capillary electrophoresis (CE), supercritical fluid chromatography (SFC) and other techniques are used for separation and quantification. A derivatization reaction can be used to confirm the identity and quantity of the separated mycotoxins (Pereira et al., 2014; Kralj Cigić \& Prosen, 2009). Derivatization is commonly required to enhance the response for determination of mycotoxins. Typical choices are pre-column with trifluoroacetic acid (TFA) (Benvenuti \& Di Gioia), o-phthalaldehyde (OPA) (Piacentini et al., 2015-A) and pentafluoropropionic anhydride (PFPA) (Ibáñez-Vea et al., 2012).

In this review we have focused on various sample preparation techniques, screening methods and chromatographic methods for the analysis of mycotoxins in the most important matrices of brewing industry such as barley, malt and beer. The review provides insights into nearly two decades of research on mycotoxins in brewing, malting, and not just of them. In addition, the latest findings on mycotoxin determination are presented.

\section{Determination of mycotoxins}

Due to the low levels at which mycotoxins are usually present in barley, malt and beer as well as general restrictive guidelines concerning the maximum acceptable levels, robust and selective methods are required for their sensitive and accurate determination. Most analytical methods have the common following steps: sampling, homogenization, extraction followed by a clean-up step to reduce or eliminate matrix effects, and finally the separation and detection, usually a chromatographic technique in combination with a variety of detectors (Pereira et al., 2014; Kralj Cigić \& Prosen, 2009).

\subsection{Sampling}

Sampling plays a critical role in how precise the determination of mycotoxin levels is due to the fact that the molds that generate mycotoxins do not grow uniformly on the substrate and existing contamination in natural samples is not homogeneous. A study demonstrated that the actual mycotoxin concentration of a bulk lot cannot be determined with $100 \%$ certainty due to the variability associated with each step in the mycotoxin test procedure. Thus, the sampling procedure could dramatically impact the final results regarding the determination of 
mycotoxins. The sampling step typically represents the largest source of error due to the extreme distribution of mycotoxins among kernels within the lot. Therefore, a reasonable sampling plan will help to minimize the risk of misclassifying the product, which could further facilitate trade as well as provide consumer protection. Thus, it is suggested that researchers should pay more attention to the sampling procedure in the future studies (Zhang et al., 2018). Therefore, the homogenization of the sample is also a very critical point in the analysis of mycotoxins.

\subsection{Extraction}

The purpose of extraction is to remove mycotoxins from the matrix as completely as possible into a solvent that is suitable for subsequent clean-up or direct analysis. The extraction solvent and method used are the two most important considerations for the extraction procedure. The selection of the extraction solvent depends on several things, including physical and chemical characteristics of the analyte, solvent cost and safety, the solubility of the non-analyte in the extraction solvent and subsequent processing steps following extraction. Ideally, the extraction solvent should remove only the mycotoxin of interest from the sample matrix. However, due to the complex matrix and the absence of a completely specific extraction solvent, the extraction solvent used should be adjusted according to the characteristics of both the analyte and associated matrix (Zhang et al., 2018). Currently, the most common solvents used for the extraction of mycotoxins are methanol, acetonitrile, chloroform, dichloromethane, ethyl acetate or acetone with small amounts of diluted acids or water. The addition of water or acidified water solution (i.e. with formic acid, acetic acid and citric acid) usually improves the efficiency of extraction, because water increases penetration of the solvent into the material and an acid solution can help the extraction by breaking interactions between the toxins and other sample constituents (Rahmani et al., 2009). Currently, a mixture of acetonitrile/water (in 84/16 and $75 / 25 \mathrm{v} / \mathrm{v}$ ratios) is the most widely used solvent for multi-mycotoxinextraction in cereal commodities (Pereira et al., 2014; Václavíková et al., 2014).

In addition to the conventional solid-liquid extraction (SLE) procedures more recent techniques including supercritical fluid extraction (SFE), pressurized liquid extraction (PLE), also known as accelerated solvent extraction (ASE), and microwave-assisted extraction (MAE) have been used for the determination of mycotoxins. They are also solid-liquid extraction methodologies; however, while in the classical SLE version, mechanical shaking or ultrasound are used to favor the extraction, in these re- cent methodologies another type of energy input is needed. They have the advantage of requiring smaller volumes of solvent and usually provide better extraction efficiencies (in terms of extraction yield and/or recovery) when compared with conventional SLE. Solid phase extraction (SPE) is another possibility for direct extraction of liquid samples, most often used in mycotoxin analysis for cleanup and pre-concentration of extracts. Originally, SPE has been performed on broad-range, non-specific stationary phases (reverse-phase, normal-phase, ion exchange, activated carbon etc.), while recently there has been greater emphasis on the use of another type of materials, which enable a very selective binding of target molecules and sometimes also higher recoveries. The most popular are immunoaffinity materials, while molecularly imprinted polymers (MIP) are an emerging, cheaper and very promising alternative. Immunoaffinity extraction (IAE) is performed generally for all mycotoxins in very diverse matrices. The IAC are not absolutely selective for individual mycotoxins, as also mycotoxin analogues are usually bound to the material. Special extraction techniques such as salting-out assisted liquid-liquid extraction (SALLE) (Mariño-Repizo, et al., 2018), solid-phase microextraction (SPME) and dispersive liquid-liquid microextraction (DLLME) are extractive techniques that do not require any additional clean-up step, because extraction itself allows a clean-up of the enriched extract, ready to be analyzed (Pereira et al., 2014; Kralj Cigić \& Prosen, 2009; Șenyuva \& Gilbert, 2010). A combined extractive/clean-up extraction technique is the method QuEChERS (acronymic name from quick, easy, cheap, effective, rugged and safe). QuEChERS is a technique initially developed by Anastassiades, M., Lehotay, S. J., Štajnbaher, D., \& Schenck, F. J. (2003) for extraction of pesticides with a wide polarity range from fruits and vegetables. This method consists of an extraction with acetonitrile followed by centrifugation after the addition of salts. There are three dominant different modifications of the QuEChERS method for extraction and clean-up analyte: original QuEChERS method, citrate buffered QuEChERS method (EU version) and acetate buffered QuEChERS method (AOAC version) (Andraščíková, M., \& Hrouzková, S. 2013). The QuEChERS method was tested in beer-based drinks such asbeer, low-malt beer, new genre and nonalcoholic beer. The characteristic features of the originál QuEChERS method are as follows: (1) extraction with acetonitrile in a disposable tube, followed by the salting out and removal of water from acetonitrile using sodium chloride $(\mathrm{NaCl})$ and anhydrous magnesium sulphate (MgSO4); (2) purification with dispersive solid phase extraction (d-SPE), in which extract is processed by shaking with either primary-secondary amine (PSA), silica gel alone, or PSA plus C18 or graphite carbon black 
(GCB). The biggest advantage of using this method is that the time required to perform the assay is reduced, since there are only two steps involved (Tamura et al. 2011).

\subsection{Clean-up}

Current reference methods for quantitative analysis of mycotoxins are based on a common strategy. After an extraction, the sample extract is purified by immunoaffinity columns (IAC) and detected. These methods offer unequalled performances for achieving a high sensitivity in a wide range of matrices and continue to receive considerable attention from researchers. Nevertheless, these methods are limited to a single compound or to certain classes of mycotoxins. This broad diversity of extraction and clean-up procedures leads to a heavy workload requiring considerable human and material resources. To simplify the analytical strategy for mycotoxin analysis, the use of multiresidue methods by liquid chromatography tandem mass spectrometry (LC-MS/MS) has become the technique of choice. Thanks to inherent selectivity of MS/MS detection in the multiple reaction monitoring (MRM) mode, fast and easy methods without or with minimal clean-up have been developed. In particular, the QuEChERS method prior to LC-MS/MS analysis received increasing attention in the mycotoxin area. The main reason was the coverage of different groups of mycotoxins with very distinct physico-chemical properties in different matrices. Nevertheless, employing basic cleanup for multi-residue analysis in complex matrices leads unavoidably to matrix effects. Due to signal suppression (more prevalent than signal enhancement), matrix effects affect sensitivity. Hence, for these specific compounds in foods, multi-residue approach is often neglected in favor of dedicated methodologies making use of specific clean-up with immunoaffinity column (IAC). Matrix effects also challenge the accuracy of LC-MS/MS methods. Matrix-matched calibration curve is frequently questioned considering the difficulty to find a perfect matrix representative for each commodity. Either the standard addition or the isotope dilution approaches represent the remaining reliable alternatives (Desmarchelier et al. 2014). Moreover, in addition to the above-mentioned clean-up methods, we can use conventional SPE, special SPE, home-made cartridges for SPE and IAC, one-step extraction, and new adsorbents of advanced nanomaterials, including carbon nanomaterials and magnetic carbon nanomaterials (Zhang et al., 2018).

\subsection{Analytical techniques}

Screening methods are very important tools for monitoring mycotoxins in food and feed. Most of the methods correspond to mere qualitative tests able to demonstrate the presence or absence of the toxin, although there are also a variety of rapid tests providing semi-quantitative or quantitative results. Among the screening methods belong immunochemical methods, which include ELISA, biosensors assays, and non-invasive methods based on infrared and acoustic techniques that have shown a great potential for mycotoxin analysis. Immunochemical methods are based on the interaction between mycotoxins (acting as antigen) and selected antibodies, which, although specific for a particular compound, can show considerable cross-reactivity for structural analogs, because they act by recognizing specific chemical groups, known as epitopes. Biosensor assays are composed of one antibody, which reacts selectively with the mycotoxin of interest, and a transducing element responsible for converting the physical variable produced by the reaction into a measurable signal (Meneely et al. 2011; Kralj Cigić \& Prosen, 2009). Other screening methods use nondestructive techniques, because screening situations require rapid detection and prompt decision-making. One attractive strategy is the in situ analysis, for example that using infrared spectrometry (IR) techniques such as near-infrared spectrometry (NIR) or Fourier-transform infrared spectrometry (FT-IR). This spectrometric technique is based on the measurement of absorption or emission of a given radiation incident on the sample (Pojić \& Mastilović, 2013). Another technique that has shown promising results for the rapid screening of mycotoxins is Raman spectrometry, a non-destructive approach requiring no sample-extraction steps. Liu, Y., Delwiche, S. R., \& Dong, Y. (2009) used this methodology for rapid screening of DON in barley. Capillary electrophoresis (CE) is a family of electrokinetic separation methods performed in submillimeter diameter capillaries using fluorescence or UV absorbance. In CE method, analytes migrate through electrolyte solutions under the influence of an electric field. and can be separated according to ionic mobility and/or partitioning into an alternate phase via non-covalent interactions (Alshannaq, A., \& Yu, J. H., 2017). A number of mycotoxins such as AFs, DON, fumonisins, OTA and ZON have been separated by CE (Maragos, C., 1998). TLC was also used as a screening method; however, nowadays it has been almost completely substituted by other methods (Kralj Cigić \& Prosen, 2009). Nevertheless, the application of such techniques is still limited to screening purposes due to a high matrix dependence and lack of appropriate calibration materials. The advantages and disadvantages of the methods used for the determination of mycotoxins are reviewed in Table 2.

All in all, chromatographic methods, such as liquid chromatography and gas chromatography are the most commonly used techniques for mycotoxin analysis 
(Zhang et al., 2018), as shown in Fig. 1B. Chromatographic methods such as HPLC or UPLC coupled with ultraviolet (UV), photodiode array (PDA), fluorescence (FLR), or mass spectrometry (MS) have been developed. Additionally, gas chromatography (GC) coupled with electron capture (ECD), flame ionization (FID), or MS detectors has been used to identify and quantitate the volatile mycotoxin patulin (Pereira et al., 2014). Due to the low volatility, GC analysis often requires a derivatization step; therefore, this method is used rarely in mycotoxin analysis (Orata, F., 2012). Liquid chromatography with mass spectrometry is the most popular method for the determination of mycotoxins in foods and feeds (Rahmani et al., 2009), other chromatographic techniques being seldom used due to their limited sensitivity and specificity (Anfossi, Giovannoli \& Baggiani, 2016).

The first LC-MS methods for the determination of trichothecenes were based on fast-atom bombardment
(FAB), thermospray, and plasmaspray ionization (Kostiainen, 1991). Later, soft-ionization techniques such as atmospheric pressure chemical ionization (APCI), electrospray ionization (ESI), and atmospheric pressure photo-ionization (APPI) were widely used, which are suitable for different molecular weights and polarity of compounds. In addition, there are many types of mass analyzers such as quadrupole $(\mathrm{Q})$, time-of-flight (TOF), ion-trap, and Fourier transform-ion cyclotron resonance (FT-ICR); however, for mycotoxin analysis the most important mass analyzers are the triple quadrupole and the ion-trap and time of flight ones (Rahmani et al., 2009). Although the early applications of MS were employed for the analysis of single mycotoxins, the technique can simultaneously quantify over 30 mycotoxins in a single run, making it the current method of choice for detecting multiple mycotoxins in a wide variety of foods (Spanjer et al., 2008; Sulyok et al. 2006).

Table 2 Comparison of the most used methods in mycotoxin detection and quantification

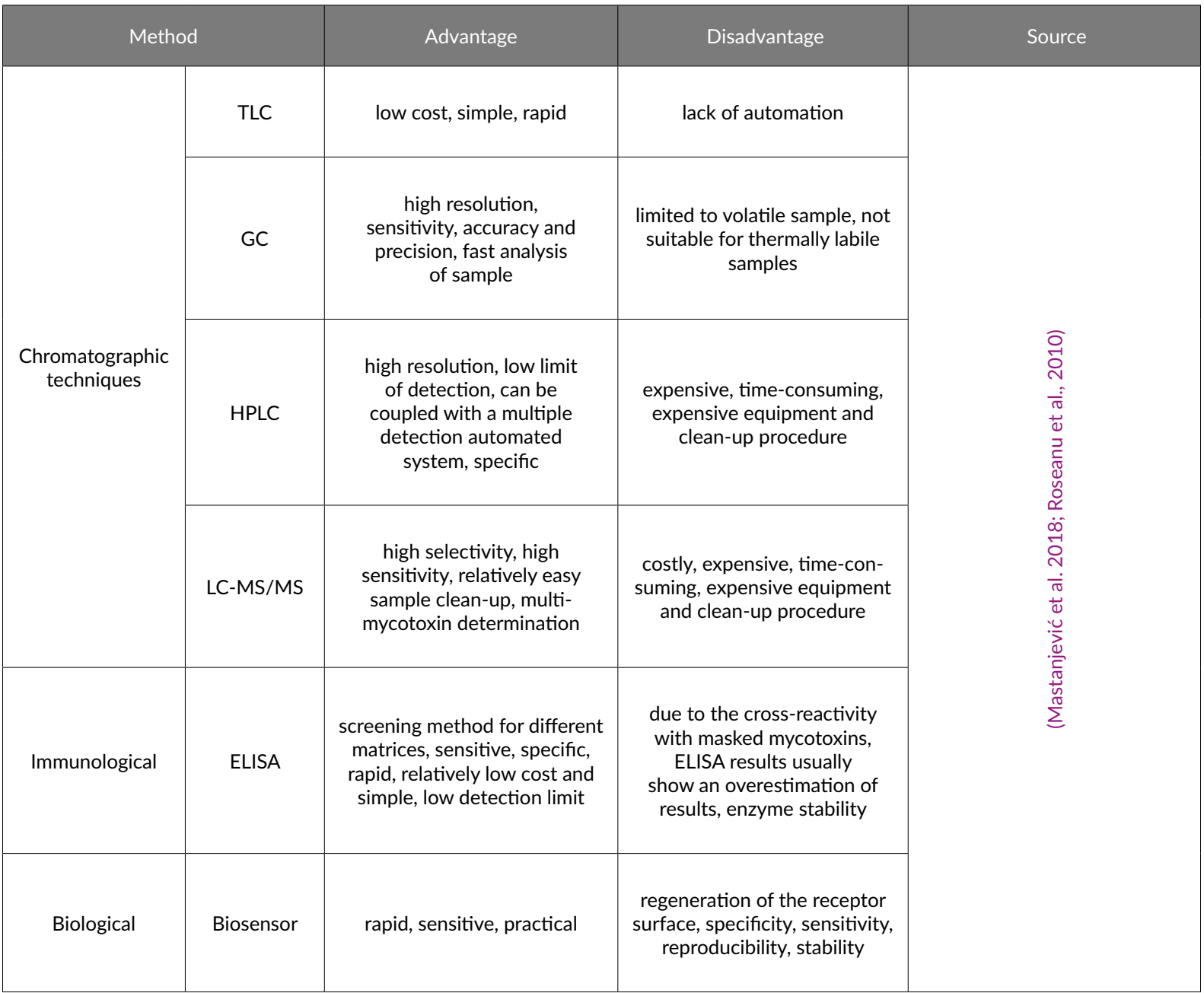


Table 3 Overview of mycotoxin analysis

\begin{tabular}{|c|c|c|c|c|c|c|}
\hline Mycotoxins & Matrix & $\begin{array}{l}\text { Extraction } \\
\text { and purification }\end{array}$ & Detection & $\begin{array}{l}\text { Levels of mycotoxins } \\
\text { range/mean [units] }\end{array}$ & Origin & Reference \\
\hline $\mathrm{T}-2$ & \multirow{4}{*}{$\begin{array}{l}\text { Barley } \\
\text { and } \\
\text { Barley prod- } \\
\text { ucts }\end{array}$} & \multirow{4}{*}{$\begin{array}{c}\text { acetonitrile-water } \\
(84: 16)\end{array}$} & \multirow{4}{*}{ LC-MS/MS } & $\mathrm{NM}-40 / 3.0[\mu \mathrm{g} / \mathrm{kg}]$ & \multirow{4}{*}{ Germany, 2009} & \multirow{4}{*}{ (Barthel et al., 2012) } \\
\hline HT-2 & & & & $\mathrm{NM}-47 / 6.8[\mu \mathrm{g} / \mathrm{kg}]$ & & \\
\hline DON & & & & $\mathrm{NM}-420 / 23[\mu \mathrm{g} / \mathrm{kg}]$ & & \\
\hline NIV & & & & $\mathrm{NM}-72 / 11[\mu \mathrm{g} / \mathrm{kg}]$ & & \\
\hline $\mathrm{T}-2$ & \multirow{4}{*}{ Barley } & \multirow{2}{*}{$\begin{array}{c}\text { acetonitrile-water } \\
(84: 16)\end{array}$} & \multirow{2}{*}{ GC-MS/MS } & $\mathrm{NM}-22.6 / 9.2[\mu \mathrm{g} / \mathrm{kg}]$ & \multirow{4}{*}{ Spain, 2007} & \multirow{4}{*}{ (Ibáñez-Vea et al., 2012) } \\
\hline HT-2 & & & & $\mathrm{NM}-16.4 / 7.8[\mu \mathrm{g} / \mathrm{kg}]$ & & \\
\hline DON & & \multirow{2}{*}{$\begin{array}{l}\text { IAC Multisep }{ }^{\circledR-227} \\
\text { Trich+ }\end{array}$} & \multirow{2}{*}{ PFPA + imidazole } & $\mathrm{NM}-119.9 / 21.7[\mu \mathrm{g} / \mathrm{kg}]$ & & \\
\hline NIV & & & & $\mathrm{NM}-12.5 / 7.4[\mu \mathrm{g} / \mathrm{kg}]$ & & \\
\hline$\Sigma$ AFs & \multirow{6}{*}{ Barley } & \multirow{6}{*}{$\begin{array}{c}\text { acetonitrile:wa- } \\
\text { ter:acetic acid } \\
(79: 20: 1)\end{array}$} & \multirow{6}{*}{ LC-MS/MS } & $0.26-2.59 / \mathrm{NM}[\mathrm{ng} / \mathrm{g}]$ & \multirow{6}{*}{ Malaysia, 2010} & \multirow{6}{*}{ (Soleimany et al., 2012) } \\
\hline OTA & & & & $0.18-2.84 / \mathrm{NM}$ [ng/g] & & \\
\hline ZON & & & & $0.95-20.26 / \mathrm{NM}$ [ng/g] & & \\
\hline DON & & & & $27.9-72.5 / \mathrm{NM}$ [ng/g] & & \\
\hline $\mathrm{T} 2$ & & & & 12.7-55.9/NM [ng/g] & & \\
\hline HT-2 & & & & $10.1-30.7 / \mathrm{NM}[\mathrm{ng} / \mathrm{g}]$ & & \\
\hline OTA & Beer & OchraTestTM & HPLC-FLR & NM-185/33 [ng/L] & Belgium & (Tangni E. K. et al.,2002) \\
\hline DON & \multirow{2}{*}{ Craft beer } & \multirow{2}{*}{ SPE column (SAX) } & LC-UV & $127-501 / 221[\mu \mathrm{g} / \mathrm{L}]$ & \multirow{2}{*}{ Brazil } & \multirow{2}{*}{ (Piacentini et al., 2015-B) } \\
\hline Fum.B1 & & & LC-FLR & $29-285 / 105[\mu \mathrm{g} / \mathrm{L}]$ & & \\
\hline \multirow[b]{2}{*}{ DON } & \multirow[b]{2}{*}{ Malting barley } & $100 \mathrm{~mL}$ pure water & \multirow[b]{2}{*}{ LC-UV } & \multirow[b]{2}{*}{$0.2-15.1 / 3.4[\mu \mathrm{g} / \mathrm{g}]$} & \multirow[b]{2}{*}{ Brazil } & \\
\hline & & $\begin{array}{c}\text { (IAC DON Test } \\
\text { HPLC) }\end{array}$ & & & & (Piacentini et al., 2015-A) \\
\hline Fum.B1 & Malting horlor & $\begin{array}{l}\text { methanol-water } \\
(80: 20)\end{array}$ & LC-FLR & $\begin{array}{c}0.001-0.013 / 0.006 \\
{[\mu g / g]}\end{array}$ & Drozil & \\
\hline Fum.B2 & Malung Dariey & $\begin{array}{l}\text { SPE column } \\
(\mathrm{N}+\mathrm{C} 18)\end{array}$ & OPA & NM-NM/0.09 [ $\mu \mathrm{g} / \mathrm{g}]$ & Brazıl & (Pıacentinı et al., 2015-A) \\
\hline DON & Malting barley & / & NIR & 0.3-50.8/NM [ppm] & / & (Ruan et al.,2002) \\
\hline DON & & & & $0-857 / 69[\mu \mathrm{g} / \mathrm{kg}]$ & & \\
\hline OTA & Malting barley & I & GC-MS & $0-934 / 76[\mu \mathrm{g} / \mathrm{kg}]$ & Sweden & (Olsson et al., 2002) \\
\hline DON & Barley & / & ELISA & $500-10000 / 4098[\mu \mathrm{g} / \mathrm{kg}]$ & $\begin{array}{c}\text { Uruguay, } \\
\text { 1996-2002 }\end{array}$ & (Pan et al., 2007) \\
\hline $\mathrm{AFB}_{1}$ & & & & $0-7.2 / 2.0[\mu \mathrm{g} / \mathrm{g}]$ & & \\
\hline ZON & & $70 \% \mathrm{MeOH}$ & & $86-202 / 132.7[\mu \mathrm{g} / \mathrm{g}]$ & & \\
\hline FUMs & Barley & & ELISA & $0-4000 / 3923.8[\mu \mathrm{g} / \mathrm{g}]$ & $\begin{array}{l}\text { Romania, } \\
\text { 2002-2004 }\end{array}$ & (Tabuc et al., 2009) \\
\hline OTA & & $50 \% \mathrm{MeOH}$ & & NM & & \\
\hline DON & & deionized water & & NM & & \\
\hline DON & & acetonitrile-water & & $\mathrm{NM}-2213.5 / 87.3[\mu \mathrm{g} / \mathrm{kg}]$ & & \\
\hline ZON & Barley & $(84: 16)$ & LC-MS/MS & $\mathrm{NM}-59.4 / 2.4[\mu \mathrm{g} / \mathrm{kg}]$ & Czech Republic, & (Běláková et al., 2014) \\
\hline$\Sigma \mathrm{T} 2, \mathrm{HT}-2$ & & $\begin{array}{c}\text { SPE column } \\
\text { (PuriTox MultiToxin) }\end{array}$ & & $\mathrm{NM}-145.0 / 8.9[\mu \mathrm{g} / \mathrm{kg}]$ & 2008-2011 & \\
\hline DON & & & & $\mathrm{NM}-\mathrm{NM} / 6.6[\mu \mathrm{g} / \mathrm{L}]$ & & \\
\hline D3G & Beer & LLE & LC-MS/MS & $\mathrm{NM}-\mathrm{NM} / 6.6[\mu \mathrm{g} / \mathrm{L}]$ & Austria, 2011 & al., 2012) \\
\hline DON & & & GC-MS & 1.0-23.0/NM $[\mu \mathrm{g} / \mathrm{L}]$ & & \\
\hline NIV & Beer & / & ACDA & $1.0-38.0 / \mathrm{NM}[\mu \mathrm{g} / \mathrm{L}]$ & Korea & (Shim et al., 1997) \\
\hline ZON & & & HFBA & / & & \\
\hline
\end{tabular}




\begin{tabular}{|c|c|c|c|c|c|c|}
\hline Mycotoxins & Matrix & $\begin{array}{l}\text { Extraction } \\
\text { and purification }\end{array}$ & Detection & $\begin{array}{l}\text { Levels of mycotoxins } \\
\text { range/mean [units] }\end{array}$ & Origin & Reference \\
\hline DON & \multirow{4}{*}{ Beer } & \multirow{4}{*}{ SPE column (C18) } & \multirow{4}{*}{ ELISA } & $1.56-6.40 / 3.42[\mathrm{ng} / \mathrm{mL}]$ & \multirow{4}{*}{ Kenya } & \multirow{4}{*}{ (Mbugua and Gathumbi, 2004) } \\
\hline Fum.B1 & & & & $0.0-0.78 / 0.30[\mathrm{ng} / \mathrm{mL}]$ & & \\
\hline ZON & & & & $4.30-10.20 / 8.16[\mathrm{pg} / \mathrm{mL}]$ & & \\
\hline $\mathrm{AFB}_{1}$ & & & & / & & \\
\hline DON & \multirow{2}{*}{ Beer } & \multirow{2}{*}{ SPE column (C18) } & \multirow{2}{*}{ ELISA } & $0.0-730.0 / 485.0[\mathrm{ng} / \mathrm{mL}]$ & \multirow{2}{*}{ Cameroon } & \multirow{2}{*}{ (Roger, 2011) } \\
\hline Fum.B1 & & & & $0.0-340.0 / 180.0[\mathrm{ng} / \mathrm{mL}]$ & & \\
\hline DON & \multirow{2}{*}{ Beer } & \multirow{2}{*}{ / } & \multirow{2}{*}{ ELISA } & $6.0-70.2 / 20.66[\mu \mathrm{g} / \mathrm{L}]$ & \multirow{2}{*}{ Poland } & \multirow{2}{*}{ (Kuzdraliński et al., 2013) } \\
\hline ZON & & & & $0-0.546 / 0.044[\mu \mathrm{g} / \mathrm{L}]$ & & \\
\hline OTA & \multirow{5}{*}{ Beer } & \multirow{5}{*}{ SPE } & \multirow{5}{*}{ LC-MS/MS } & $2.7-6.6 / \mathrm{NM}[\mu \mathrm{g} / \mathrm{L}]$ & \multirow{5}{*}{ Europe } & \multirow{5}{*}{ (Rubert et al., 2013) } \\
\hline Fum.B1 & & & & $71.2-118 / \mathrm{NM}[\mu \mathrm{g} / \mathrm{L}]$ & & \\
\hline Fum.B2 & & & & 71.0-87.0/NM [ $\mu \mathrm{g} / \mathrm{L}]$ & & \\
\hline $\mathrm{T}-2$ & & & & $4.0-12.1 / \mathrm{NM}[\mu \mathrm{g} / \mathrm{L}]$ & & \\
\hline HT-2 & & & & 15.1-20.0/NM [ $\mu \mathrm{g} / \mathrm{L}]$ & & \\
\hline DON & \multirow[b]{2}{*}{ Beer } & \multirow[b]{2}{*}{ QuEChERS } & GC-MS/MS & $24.5-47.7 / 28.9[\mu \mathrm{g} / \mathrm{L}]$ & \multirow[b]{2}{*}{ Europe } & \multirow{2}{*}{$\begin{array}{c}\text { (Rodríguez-Carrasco et al., } \\
2015)\end{array}$} \\
\hline HT-2 & & & $\begin{array}{c}\text { BSA+TMCS+ TMSI } \\
(3: 2: 3)\end{array}$ & $24.2-38.2 / 30.9[\mu \mathrm{g} / \mathrm{L}]$ & & \\
\hline DON & \multirow[t]{2}{*}{ Malting barley } & $\begin{array}{c}\text { acetonitrile-water } \\
(84: 16)\end{array}$ & \multirow[t]{2}{*}{ LC-MS/MS } & $8.5-10300 / 279[\mu \mathrm{g} / \mathrm{kg}]$ & \multirow[t]{2}{*}{ / } & \multirow[t]{2}{*}{ (Habler and Rychlik, 2016) } \\
\hline ZON & & SPE (ion exchange) & & $2.19-253 / 42.4[\mu \mathrm{g} / \mathrm{kg}]$ & & \\
\hline OTA & Beer & SALLE & UPLC-MS/MS & $0.08-0.26 / 0.12[\mu \mathrm{g} / \mathrm{L}]$ & Argentina & (Mariño-Repizo et al., 2018) \\
\hline
\end{tabular}

NM - not mentioned

\section{Conclusion}

Mycotoxin contamination of cereals is a serious concern for the food and feed industry. Especially in the brewing industry the quality of barley, which is an input raw material for the production of malt and beer, determines the quality of the final product. During the process of malting and brewing, mycotoxin contamination can by transferred into the final product, which can pose a significant risk to humans, taking into account the worldwide consumption of beer.

The most studied mycotoxins in barley and beer are DON and its derivatives, ZON, T-2 and HT-2 toxins, AFs and FMs. The most important stages of the beer production process that have an inhibitory effect on mycotoxins are steeping, kilning, mashing and fermentation. During these processes mycotoxins can be removed by drainage water, spent grains, fermentation residues, diluted or destroyed by heat treatment or absorbed on the surface. Other possible sources of contamination may be barley surrogates (maize, rice) and hops; however, it is added in too small a quantity to be considered important for the final product (Pascari et al., 2017).

In conclusion, many detection techniques have been used to determine mycotoxins in barley and beer. Although many successful methods have been identified in this area, such as the QuEChERS method followed by LC-MS/MS, there is a great opportunity for analytical chemists to continue in develop new methods to achieve higher sensitivity and solutions to other mycotoxin-related problems. One of the latest discoveries in this area is the determination of mycotoxins in beer using a biochip (Pagkali, Varvara et al., 2018). Biochips, thanks to their speed and miniaturization, represent the future development in the field of mycotoxins detection, not only in the brewing industry.

\section{Acknowledgements}

This work was supported by the Ministry of Agriculture of the Czech Republic, institutional support MZE-R01918.

\section{List of abbreviations}

$\begin{array}{ll}\text { AFB1 } & \text { aflatoxin B1 } \\ \text { AFB2 } & \text { aflatoxin B2 } \\ \text { AFG1 } & \text { aflatoxin G1 } \\ \text { AFG2 } & \text { aflatoxin G2 }\end{array}$




\begin{tabular}{|c|c|}
\hline AFs & alflatoxins \\
\hline AOAC & Association of Official Agricultural Chemists \\
\hline APCI & atmospheric pressure chemical ionization \\
\hline APPI & atmospheric pressure photo-ionization \\
\hline ASE & accelerated solvent extraction \\
\hline A-TRC & trichotecenes of type A \\
\hline BEA & beauvericin \\
\hline BSA & $\mathrm{N}, \mathrm{O}$-bis(trimethylsilyl)acetamide \\
\hline B-TRC & trichotecenes of type B \\
\hline $\mathrm{CE}$ & capillary electrophoresis \\
\hline CIT & citrinin \\
\hline DLLME & dispersive liquid-liquid microextraction \\
\hline DON & deoxynivalenol \\
\hline d-SPE & dispersive solid phase extraction \\
\hline ECD & electron capture detector \\
\hline ELISA & enzyme linked immune sorbent assay \\
\hline ENs & enniatins \\
\hline ESI & electrospray ionization \\
\hline EU & European Union \\
\hline FAB & fast atom bombardment \\
\hline FID & flame ionization detector \\
\hline FLR & fluorescence detector \\
\hline FMs & fumonisins \\
\hline FT-ICR & Fourier transform-ion cyclotron resonance \\
\hline FT-IR & Fourier-transform infrared spectrometry \\
\hline Fum.B1 & fumonisin B1 \\
\hline Fum.B2 & fumonisin B2 \\
\hline GC & gas chromatography \\
\hline GC/MS & gas chromatography/mass spectrometry \\
\hline GCB & graphite carbon black \\
\hline GC-MS/MS & gas chromatography tandem mass \\
\hline & spectrometry \\
\hline HFBA & heptafluorobutyric anhydride \\
\hline HPLC & high performance liquid chromatography \\
\hline HT-2 & HT-2 toxin \\
\hline IAC & immunoaffinity columns \\
\hline IAE & immuno affinity extraction \\
\hline IARC & $\begin{array}{l}\text { International Agency for Research } \\
\text { on Cancer }\end{array}$ \\
\hline IR & infrared spectrometry \\
\hline LC & liquid chromatography \\
\hline LC-MS & liquid chromatography/mass spectrometry \\
\hline LC-MS/MS & $\begin{array}{l}\text { liquid chromatography tandem mass } \\
\text { spectrometry }\end{array}$ \\
\hline $\log P$ & Octanol-water partition coefficient \\
\hline MAE & microwave-assisted extraction \\
\hline MIP & molecularly imprinted polymers \\
\hline MON & moniliformin \\
\hline MRM & multiple reaction monitoring \\
\hline MS & mass spectrometry \\
\hline NIR & near-infrared spectrometry \\
\hline NIV & nivalenol \\
\hline
\end{tabular}

$\begin{array}{ll}\text { OPA } & \text { o-phthalaldehyde } \\ \text { OTA } & \text { ochratoxin A } \\ \text { OTs } & \text { ochratoxins } \\ \text { PAT } & \text { patuline } \\ \text { PDA } & \text { photodiode array } \\ \text { PFPA } & \text { pentafluoropropionic anhydride } \\ \text { PLE } & \text { pressurized liquid extraction } \\ \text { PSA } & \text { primary-secondary amine } \\ \text { Q } & \text { quadrupole } \\ \text { QuEChERS } & \text { quick, easy, cheap, effective, rugged and safe } \\ \text { SALLE } & \text { salting-out assisted liquid- liquid extraction } \\ \text { SFC } & \text { supercritical fluid chromatography } \\ \text { SLE } & \text { solid-liquid extraction } \\ \text { SPE } & \text { solid phase extraction } \\ \text { SPME } & \text { solid-phase microextraction } \\ \text { T-2 T-2 } & \text { toxin } \\ \text { TFA } & \text { trifuoroacetic acid } \\ \text { TLC } & \text { thin layer chromatography } \\ \text { TMCS } & \text { (trimethylchlorosilane } \\ \text { TMSI } & \text { N-trimethylsilyl imidazole } \\ \text { TOF } & \text { time-of-flight } \\ \text { TRC } & \text { trichotecenes } \\ \text { UPLC } & \text { ultra performance liquid chromatography } \\ \text { UV } & \text { ultraviolet detector } \\ \text { WHO } & \text { World Health Organization } \\ \text { ZON } & \text { zearalenone } \\ \text { EAFs } & \text { sum of aflatoxins } \\ \text { ET2, HT-2 } & \text { sum of T-2 toxin and HT-2 toxin }\end{array}$

\section{References}

Alshannaq, A., \& Yu, J. H. (2017). Occurrence, toxicity, and analysis of major mycotoxins in food. International journal of environmental research and public health, 14(6), 632. https://doi.org/10.3390/ijerph14060632 Anastassiades, M., Lehotay, S. J., Štajnbaher, D., \& Schenck, F. J. (2003). Fast and easy multiresidue method employing acetonitrile extraction/partitioning and "dispersive solid-phase extraction" for the determination of pesticide residues in produce. Journal of AOAC international, 86(2), 412-431.

Andraščíková, M., \& Hrouzková, S. (2013). A comparative study of three modifications of the QuEChERS method for determination of endocrine disrupting pesticide residues in lemon matrices by fast GC-MS. Analytical Methods, 5(6), 1374-1384. https://doi.org/10.1039/c3ay26434c

Anfossi, L., Giovannoli, C., \& Baggiani, C. (2016). Mycotoxin detection. Current opinion in biotechnology, 37, 120-126. https://doi. org/10.1016/j.copbio.2015.11.005

Barthel, J., Gottschalk, C., Rapp, M., Berger, M., Bauer, J., \& Meyer, K. (2012). Occurrence of type A, B and D trichothecenes in barley and barley products from the Bavarian market. Mycotoxin research, 28(2), 97-106. https://doi.org/10.1007/s12550-012-0123-1

Basařová, G., Šavel, J., Basař, P., Basařová,P., Lejsek, T., 2017: The comprehensive guide to brewing. From raw material to packaging. Fachverlag Hans Carl GmbH, Nuremberg, Germany. ISBN 978-3-418-00842-4.

Bennett, J., \& Klich, M. (2003). Mycotoxins. Clinical microbiology reviews, 16(3), 497-516. https://doi.org/10.1128/CMR.16.3.497-516.2003 
Benvenuti, M. E., \& Di Gioia, A. J. Rapid Analysis Of Aflatoxins Without Derivatization Using Ultra Performance Liquid Chromatography And Fluorescence Detection. Waters Application Note.

Betina, V. (1989). Mycotoxins. Chemical, biological and environmental aspects. Elsevier.

Běláková, S., Benešová, K., Mikulíková, R., \& Svoboda, Z. Výskyt ochratoxinu A v pivech The Occurrence of Ochratoxin A in Beers.

Běláková, S., Benešová, K., Čáslavský, J., Svoboda, Z., \& Mikulíková, R. (2014). The occurrence of the selected fusarium mycotoxins in Czech malting barley. Food Control, 37, 93-98. https://doi. org/10.1016/j.foodcont.2013.09.033

Bolechová, M., Benešová, K., Běláková, S., Čáslavský, J., Pospíchalová, M., \& Mikulíková, R. (2015). Determination of seventeen mycotoxins in barley and malt in the Czech Republic. Food Control, 47, 108-113. https://doi.org/10.1016/j.foodcont.2014.06.045

Commission Regulation (EC) No 1881/2006 of 19. December 2006 setting maximum levels for certain contaminants in foodstuffs. https: / / eur-lex.europa.eu/LexUriServ/LexUriServ.do?uri=0J:L:2006:364:0005:0024:EN:PDF

Desmarchelier, A., Tessiot, S., Bessaire, T., Racault, L., Fiorese, E., Urbani, A., ... \& Mottier, P. (2014). Combining the quick, easy, cheap, effective, rugged and safe approach and clean-up by immunoaffinity column for the analysis of 15 mycotoxins by isotope dilution liquid chromatography tandem mass spectrometry. Journal of Chromatography A, 1337, 75-84. https://doi.org/10.1016/j.chroma.2014.02.025

Fung, F., \& Clark, R. F. (2004). Health effects of mycotoxins: a toxicological overview. Journal of Toxicology: Clinical Toxicology, 42(2), 217-234. https://doi.org/10.1081/CLT-120030947

Habler, K., \& Rychlik, M. (2016). Multi-mycotoxin stable isotope dilution LC-MS/MS method for Fusarium toxins in cereals. Analytical and bioanalytical chemistry, 408(1), 307-317. https://doi.org/10.1007/ s00216-015-9110-7

International Agency for Research on Cancer. IARC.(1993). Evaluation of carcinogenic risks of chemical to humans. In "Some naturally-occurring substances: Food Items and Constituents". Heterocyclic Aromatic Amines and Mycotoxins. IARC monographs, Lyon, France, 359-362.

IARC Working Group on the Evaluation of Carcinogenic Risks to Humans, World Health Organization, \& International Agency for Research on Cancer. (2002). Some traditional herbal medicines, some mycoto-xins, naphthalene and styrene (No. 82). World Health Organization.

IARC (2010). Alcohol consumption and ethyl carbamate. IARC Monogr Eval Carcinog Risks Hum, 96: 1-1428.

Ibáñez-Vea, M., Lizarraga, E., González-Peñas, E., \& de Cerain, A. L. (2012). Co-occurrence of type-A and type-B trichothecenes in barley from a northern region of Spain. Food Control, 25(1), 81-88. https://doi.org/10.1016/j.foodcont.2011.10.028

Kostiainen, R. (1991). Identification of trichothecenes by thermospray, plasmaspray and dynamic fast-atom bombardment liquid chromatography-mass spectrometry. Journal of Chromatography B: Biomedical Sciences and Applications, 562(1-2), 555-562. https://doi.org/10.1016/0378-4347(91)80607-E

Kralj Cigić, I., \& Prosen, H. (2009). An overview of conventional and emerging analytical methods for the determination of mycotoxins. International journal of molecular sciences, 10(1), 62-115. https:// doi.org/10.3390/ijms10010062

Kuzdraliński, A., Solarska, E., \& Muszyńska, M. (2013). Deoxynivalenol and zearalenone occurence in beers analysed by an enzyme-linked immunosorbent assay method. Food Control, 29(1), 22-24. https:// doi.org/10.1016/j.foodcont.2012.06.003

Liu, Y., Delwiche, S. R., \& Dong, Y. (2009). Feasibility of FT-Raman spec- troscopy for rapid screening for DON toxin in ground wheat and barley. Food Additives and Contaminants, 26(10), 1396-1401. https:// doi.org/10.1080/02652030903013310

Malachova, A., Varga, E., Schwartz, H., Krska, R., \& Berthiller, F. (2012). Development, validation and application of an LC-MS/MS based method for the determination of deoxynivalenol and its conjugates in different types of beer. World Mycotoxin Journal, 5(3), 261-270. https://doi.org/10.3920/WMJ2012.1425

Maliŕ, F., \& Ostrý, V. (2003). Vláknité mikromycety (plísně), mykotoxiny a zdraví člověka. Národní centrum ošetřovatelství a nelékařských zdravotnických oborů.

Maragos, C. (1998). Analysis of mycotoxins with capillary electrophoresis. In Seminars in Food Analysis (Vol. 3, pp. 353-374). CHAPMAN \& HALL.

Mariño-Repizo, L., Goicoechea, H., Raba, J., \& Cerutti, S. (2018). A simple, rapid and novel method based on salting-out assisted liquid-liquid extraction for ochratoxin A determination in beer samples prior to ultra-high performance liquid chromatography coupled to tandem mass spectrometry. Food Additives \& Contaminants: Part A, (just-accepted).

Mastanjević, K., Krstanović, V., Mastanjević, K., \& Šarkanj, B. (2018). Malting and Brewing Industries Encounter Fusarium spp. Related Problems. Fermentation, 4(1), 3. https://doi.org/10.3390/fermentation 4010003

Mbugua, S. K., \& Gathumbi, J. K. (2004). The contamination of Kenyan lager beers with Fusarium mycotoxins. Journal of the Institute of Brewing, 110(3), 227-229. https://doi.org/10.1002/j.2050-0416. 2004.tb00207.x

Meneely, J. P., Ricci, F., van Egmond, H. P., \& Elliott, C. T. (2011). Current methods of analysis for the determination of trichothecene mycotoxins in food. TrAC Trends in Analytical Chemistry, 30(2), 192-203. https://doi.org/10.1016/j.trac.2010.06.012

Moake, M. M., Padilla-Zakour, O. I., \& Worobo, R. W. (2005). Comprehensive review of patulin control methods in foods. Comprehensive Reviews in Food Science and Food Safety, 4(1), 8-21. https://doi. org/10.1111/j.1541-4337.2005.tb00068.x

Njumbe Ediage, E., Diana Di Mavungu, J., Monbaliu, S., Van Peteghem, C., \& De Saeger, S. (2011). A validated multianalyte LC-MS/MS method for quantification of 25 mycotoxins in cassava flour, peanut cake and maize samples. Journal of agricultural and food chemistry, 59(10), 5173-5180. https://doi.org/10.1021/jf2009364

Olsson, J., Börjesson, T., Lundstedt, T., \& Schnürer, J. (2002). Detection and quantification of ochratoxin A and deoxynivalenol in barley grains by GC-MS and electronic nose. International Journal of Food Microbiology, 72(3), 203-214. https://doi.org/10.1016/S01681605(01)00685-7

Orata, F. (2012). Derivatization reactions and reagents for gas chromatography analysis. In Advanced Gas Chromatography-Progress in Agricultural, Biomedical and Industrial Applications. InTech. https://doi.org/10.5772/33098

Ough CS (1987). Chemicals used in making wine. Chem Eng News, 65: 19-28. https://doi.org/10.1021/cen-v065n001.p019

Pagkali, V., Petrou, P. S., Makarona, E., Peters, J., Haasnoot, W., Jobst, G., \& Misiakos, K. (2018). Simultaneous determination of aflatoxin B1, fumonisin B1 and deoxynivalenol in beer samples with a label-free monolithically integrated optoelectronic biosensor. Journal of hazardous materials, 359, 445-453. https://doi.org/10.1016/j. jhazmat.2018.07.080

Pan, D., Bonsignore, F., Rivas, F., Perera, G., \& Bettucci, L. (2007). Deoxynivalenol in barley samples from Uruguay. International journal of food microbiology, 114(2), 149-152. https://doi. org/10.1016/j.ijfoodmicro.2006.08.006

Pascari, X., Ramos, A. J., Marín, S., \& Sanchis, V. (2017). Mycotoxins and 
beer. Impact of beer production process on mycotoxin contamination. A review. Food Research International.

Pereira, V. L., Fernandes, J. O., \& Cunha, S. C. (2014). Mycotoxins in cereals and related foodstuffs: A review on occurrence and recent methods of analysis. Trends in Food Science \& Technology, 36(2), 96-136. https://doi.org/10.1016/j.tifs.2014.01.005

Pettersson, H., Brown, C., Hauk, J., Hoth, S., Meyer, J., \& Wessels, D. (2011). Survey of T-2 and HT-2 toxins by LC-MS/MS in oats and oat prod ucts from European oat mills in 2005-2009. Food Additives and Contaminants: Part B, 4(2), 110-115. https://doi.org/10.1080/ 19393210.2011.561933

Piacentini, K. C., Savi, G. D., Pereira, M. E., \& Scussel, V. M. (2015). Fungi and the natural occurrence of deoxynivalenol and fumonisins in malting barley (Hordeum vulgare L.). Food chemistry, 187, 204-209. https://doi.org/10.1016/j.foodchem.2015.04.101

Piacentini, K. C., Savi, G. D., Olivo, G., \& Scussel, V. M. (2015). Quality and occurrence of deoxynivalenol and fumonisins in craft beer. Food Control, 50, 925-929. https://doi.org/10.1016/j.foodcont.2014.10.038

Pojić, M. M., \& Mastilović, J. S. (2013). Near infrared spectroscopyadvanced analytical tool in wheat breeding, trade, and processing. Food and Bioprocess Technology, 6(2), 330-352. https://doi.org/ 10.1007/s11947-012-0917-3

Rahmani, A., Jinap, S., \& Soleimany, F. (2009). Qualitative and quantitative analysis of mycotoxins. Comprehensive reviews in food science and food safety, 8(3), 202-251. https://doi.org/10.1111/j.1541-4337. 2009.00079.x

Rodríguez-Carrasco, Y., Fattore, M., Albrizio, S., Berrada, H., \& Mañes, J. (2015). Occurrence of Fusarium mycotoxins and their dietary intake through beer consumption by the European population. Food chemistry, 178, 149-155. https://doi.org/10.1016/j.foodchem. 2015.01.092

Roger, D. D. (2011). Deoxynivalenol (DON) and fumonisins B1 (FB1) in artisanal Sorghum opaque beer brewed in north Cameroon. African Journal of Microbiology Research, 5(12), 1565-1567. https://doi. org/10.5897/AJMR10.709

Roseanu, Anca, Jecu, Luiza., Badea, Mihaela, \& Evans, R. W. (2010). Mycotoxins: An overview on their quantification methods. Romanian Journal of Biochemistry, 47(1), 79-86.

Ruan, R., Li, Y., Lin, X., \& Chen, P. (2002). Non-destructive determination of deoxynivalenol levels in barley using near-infrared spectroscopy. Applied Engineering in Agriculture, 18(5), 549. https://doi.org/ 10.13031/2013.10141

Rubert, J., Soler, C., Marín, R., James, K. J., \& Mañes, J. (2013). Mass spectrometry strategies for mycotoxins analysis in European beers. Food Control, 30(1), 122-128. https://doi.org/10.1016/ j.foodcont.2012.06.035

Șenyuva, H. Z., \& Gilbert, J. (2010). Immunoaffinity column clean-up techniques in food analysis: A review. Journal of Chromatography B, 878(2), 115-132. https://doi.org/10.1016/j.jchromb.2009.05.042

Shim, W. B., Kim, J. C., Seo, J. A., \& Lee, Y. W. (1997). Natural occurrence of trichothecenes and zearalenone in Korean and imported beers. Food Additives \& Contaminants, 14(1), 1-5. https://doi.org/ $10.1080 / 02652039709374490$

Siegel, D., \& Babuscio, T. (2011). Mycotoxin management in the European cereal trading sector. Food Control, 22(8), 1145-1153. https://doi. org/10.1016/j.foodcont.2011.02.022

Soleimany, F., Jinap, S., \& Abas, F. (2012). Determination of mycotoxins in cereals by liquid chromatography tandem mass spectrometry. Food chemistry, 130(4), 1055-1060. https://doi.org/10.1016/j.foodchem.2011.07.131
Speijers, G. J. A., \& Speijers, M. H. M. (2004). Combined toxic effects of mycotoxins. Toxicology letters, 153(1), 91-98. https://doi. org/10.1016/j.toxlet.2004.04.046

Spanjer, M. C., Rensen, P. M., \& Scholten, J. M. (2008). LC-MS/MS multi-method for mycotoxins after single extraction, with validation data for peanut, pistachio, wheat, maize, cornflakes, raisins and figs. Food Additives and Contaminants, 25(4), 472-489. https://doi. org/10.1080/02652030701552964

Sulyok, M., Berthiller, F., Krska, R., \& Schuhmacher, R. (2006). Development and validation of a liquid chromatography/tandem mass spectrometric method for the determination of 39 mycotoxins in wheat and maize. Rapid Communications in Mass Spectrometry: An International Journal Devoted to the Rapid Dissemination of Upto-the-Minute Research in Mass Spectrometry, 20(18), 2649-2659. https://doi.org/10.1002/rcm.2640

Tabuc, C., Marin, D., Guerre, P., Sesan, T., \& Bailly, J. D. (2009). Molds and mycotoxin content of cereals in southeastern Romania. Journal of food protection, 72(3), 662-665. https://doi.org/10.4315/0362028X-72.3.662

Tamura, M., Uyama, A., \& Mochizuki, N. (2011). Development of a multimycotoxin analysis in beer-based drinks by a modified QuEChERS method and ultra-high-performance liquid chromatography coupled with tandem mass spectrometry. Analytical sciences, 27(6), 629-629. https://doi.org/10.2116/analsci.27.629

Tangni, E. K., Ponchaut, S., Maudoux, M., Rozenberg, R., \& Larondelle, Y. (2002). Ochratoxin A in domestic and imported beers in Belgium: occurrence and exposure assessment. Food Additives \& Contaminants, 19(12), 1169-1179. https://doi.org/10.1080/02652030210007859

Turner, N. W., Subrahmanyam, S., \& Piletsky, S. A. (2009). Analytical methods for determination of mycotoxins: a review. Analytica chimica acta, 632(2), 168-180. https://doi.org/10.1016/j.aca.2008.11.010

Vaclavikova, M., Vaclavik, L., \& Cajka, T. (2014). High-throughput analysis of mycotoxins. High-throughput analysis for food safety. Wiley, Hoboken, 231-266. https://doi.org/10.1002/9781118907924.ch08

WHO (2004). Global Status Report on Alcohol. Geneva, World Health Organization.

Zaied, C., Zouaoui, N., Bacha, H., \& Abid, S. (2012). Natural occurrence of citrinin in Tunisian wheat grains. Food Control, 28(1), 106-109. https://doi.org/10.1016/j.foodcont.2012.04.015

Zhang, L., Dou, X. W., Zhang, C., Logrieco, A. F., \& Yang, M. H. (2018). A review of current methods for analysis of mycotoxins in herbal medicines. Toxins, 10(2), 65. https://doi.org/10.3390/toxins10020065

Zöllner, P., \& Mayer-Helm, B. (2006). Trace mycotoxin analysis in complex biological and food matrices by liquid chromatography-atmospheric pressure ionisation mass spectrometry. Journal of Chromatography A, 1136(2), 123-169. https://doi.org/10.1016/j.chroma.2006.09.055 